\title{
ANALYSIS OF THE IMPLEMENTATION OF THE EVALUATION OF GUIDANCE AND COUNSELLING PROGRAM AT STATE SENIOR HIGH SCHOOLS OF SINGKAWANG
}

\author{
Abd. Basith \\ Sekolah Tinggi Keguruan dan IImu Pendidikan \\ (STKIP) Singkawang \\ abdullahalbasith@gmail.com
}

\begin{abstract}
The objectives of this research are: (1) to describe and analyze the implementation of the guidance and counselling program at State Senior High School of Singkawang, and (2) to find some factors inhibiting the implementation of the guidance and counselling program at State Senior High School of Singkawang. This study uses qualitative methods; using interview data collecting technique, tested its validity through triangulation. The subjects in this study are all teachers of guidance and counselling in the Senior High School of Singkawang as many as 10 people as well as principals and supervisors as the informants with the total of 11 people. The data analysis techniques are in form of data reduction, presentation and conclusion. The results show that: (1) the implementation of evaluation of guidance and counselling program by the teachers still has many weaknesses on each phase of the evaluation, such as not understanding the evaluation models of the guidance and counselling program, how to apply them, and monitoring process that is not done in deeply and in detail (just what it is), (2) Some factors inhibiting the implementation of the evaluation of guidance and counselling program are lack of knowledge and understanding of the evaluation of guidance and counselling program in the schools, lack of interest in developing professional competencies, and lack of guidance to the teachers in implementing the guidance and counselling evaluation program.
\end{abstract}

\section{Indexing terms/Keywords}

Implementation of the Evaluation of Guidance and Counselling Program

\section{Academic Discipline And Sub-Disciplines}

Guidance and Counseling, Education

\section{SUBJECT CLASSIFICATION}

Evaluation of Education

\section{TYPE (METHOD/APPROACH)}

Phenomenological; Qualitative research

\section{INTRODUCTION}

Guidance and counselling means providing support services to the students to be able to recognize, understand, and actualize themselves, adjust them to their environment, plan for their future, solve all the problems in such ways that their development process can be optimally passed. The guidance and counseling as one of educational activities has a strategic position in the students' personal development not touched by regular teaching and training activities. Since this strategic position, guidance and counseling in schools should not only act just as a "spectator" but also actively move based on its functions and roles, one of them is by organizing guidance and counseling program. Winkel and Sri Hastuti (2004: 91) defined that "guidance and counseling program is a series of planned, organized and coordinated guidance activities during a certain time period, for example in one academic year". Guidance and counseling program is essential for the achievement of learning objectives designed as a means to enhance the students' creativity for a well-planned and organized development. This is in line with Rochman Natawidjadja (1978: 30) which stated that "A well-arranged and detailed guidance and counseling program will provide many benefits both for individuals receiving assistance (for their own development) as well as officers providing guidance in achieving more planned and organized objectives".

The success level of the guidance and counselling program can be determined by conducting an evaluation of the program. The evaluation of the guidance and counselling program can essentially help the teachers of guidance and counselling to further determine and identify the successful implementation of guidance and counselling program that has been planned. Continuous and sustainable evaluation of the guidance and counselling program is necessary, to improve the implementation of guidance and counselling program in the schools in order to bring better changes, both in developing the next program and in the educational world. This is in line with the statement proposed by Gibson and Mitchell (2011: 56) that "the evaluation of guidance and counselling is a method or process of assessing the effectiveness 
of counsellor's activities. It is fundamental for the verification and improvement of the profession and performance of the program".

Besides being used as an improvement material, the evaluation can also be used in making a decision. The decision in question is related with the program that has been run, whether the existing program will be continued or revised with various improvements. Arikunto S. and Cepi (2004: 1) stated that "evaluation is an activity to gather information about the workings of something, which then the information is used to determine an appropriate alternative in taking a decision". The evaluation is also used to identify, clarify, and apply certain criteria that can be maintained to determine the evaluation of an object's values and services related with those criteria. This is in accordance with Fitzpatrick, J.L. et al (2004: 27) explaining that "Evaluation is the identification, clarification, and application of defensible criteria to determine an evaluation object's value, its merit or worth, in regard to those criteria. The specification and use of explicit criteria distinguish formal evaluation from the informal evaluations most of use make daily".

The evaluation of guidance and counselling is described by Gysbers and Henderson (2006: 323) that "three kinds of systematic evaluation are required to achieve accountability for your guidance and counseling program is personnel evaluation, program evaluation and results evaluation". It can be explained that the focus of the evaluation in guidance and counselling is divided into three, namely personnel, process and results evaluation.

Besides the focus on assessment, other important things to be studied are some aspects that will be assessed in the evaluation of the implementation of guidance and counselling program. According to Sugiyo (2011: 105) there are six aspects that need to be assessed in the evaluation of guidance and counseling program, namely (1) fitness between the program and its implementation, (2) adherence of the program, (3) obstacles encountered, (4) impacts of guidance services on teaching and learning activities, (5) responses from the students, school's personnels, parents, and communities on the guidance services, and (6) changes on the learners' progress seen from the achievement of the objectives of guidance and counseling program, developmental tasks, learning outcomes and the students' achievement after completing their study.

A well and correct implementation of the evaluation of guidance and counseling program will contribute to a better change, both for the guidance and counseling teachers and various parties concerned. Joseph (2009: 106) explained that there are two functions of the evaluation of guidance and counseling in the schools, namely (1) to provide feedbacks to the supervising teachers or counselors to improve or develop the guidance and counseling program, (2) to provide information to leadership board of the school, subject teachers, and parents about the development of students' attitudes and behavior or the level of achievement of students' developmental tasks to collaborate and improve the quality of the implementation of guidance and counseling program in the schools.

The evaluation of guidance and counseling program must be implemented correctly and properly when following certain stages. According to Gysbers and Henderson (2006), the evaluation stages includes six aspects: (1) determining the program components to be assessed, (2) selecting an evaluation model to be used, (3) selecting assessment instruments, (4) determining data collection procedure, (5) creating a monitoring system of the implementation of the program, (6) presenting and analyzing the data, and evaluation report.

The guidance and counseling teachers as the professional educators should have competencies or abilities to carry out guidance and counseling management, one of which is the ability to implement the evaluation program (Dirjen PMPTK, 2007: 57). Using this ability, they can develop the guidance and counseling program based on the students' needs properly, so that the program will have strong impacts on the students' development more optimally.

However, the expected demands are not always correspond with the reality. There are still many students that intentionally miss the classes or lack of achievements according to their actual capabilities, lateness, absenteeism, smoking, fighting with their friends, and many other problems faced by the students which resulted in delays in their development, both in academic, personal and social relationships. Gibson and Mitchell (2011: 579) stated that "the lack of evaluation often leads to mediocrity or failure to achieve individual potential, based on what a professional should be achieved for the sake of the clients they serve. Avoiding the evaluation means the program has still many weaknesses and potential to fail".

These kinds of problems are continuously faced by the counsellors from year to year and almost no change. This is all due to the guidance and counselling program is not arranged based on the students' needs. The problems experienced by the students can naturally be overcome if the guidance and counselling program designed is periodically evaluated so that there will be significant improvements in accordance with the students' needs and concerns. This is in line with the research conducted by Daniel L. Staffelbeam (2003), researching "Institutionalizing Evaluation in Schools". Evaluation is a systematic process of judging the goodness and/or worthy of a program or other objects, and it is important for the success of the schools or other social enterprises. Functional evaluation system of the school assesses all important aspects of the school, providing direction to improve and maintain accountability records, and enhance understanding on the teaching, learning and other school processes. This study considers that the evaluation is strongly required as a tool to determine the success or viability of a program.

Based on the findings above, the writer is encouraged to hold a research and identify the implementation of the evaluation of guidance and counseling program as well as various constraints/problems experienced by the guidance and counseling teachers in State Senior High School of Singkawang in evaluating the guidance and counseling program. This research is taken place at the State Senior High School (SMA) in Singkawang which has considerably adequate guidance and 
counseling program. The state school is chosen due to high level of credibility, and the teachers' skills in implementing the guidance and counseling evaluation will impact the quality of students' services in the schools.

The results of this study can be used as input for the schools, education offices, LPMP (Educational Quality Insurance Organization) and academics in providing guidance to the guidance and counseling teachers related with the expertise in evaluating the guidance and counseling program in the schools.

\section{RESEARCH METHODS}

This study uses qualitative research in phenomenological perspective. According to Husserl, (Moleong, 2014) "phenomenological perspective is an approach to gain knowledge of things (objects) and be the experience of human consciousness". Phenomenological qualitative method is used to uncover the evaluation of guidance and counseling programs in the schools by the research subjects. The focus of this study is the evaluation of the implementation of the guidance and counseling program in the State Senior High Schools (SMAN) in Singkawang. The research subjects are the guidance and counselling teachers of the state senior high schools in Singkawang, while the supervisors and principals act as the informants. The data collection technique used is in-depth interview analyzed in three stages, namely data reduction, data presentation and conclusion (Miles and Huberman, the Sugiyono, 2009: 246). The validity test uses sources triangulation, by comparing or checking the data obtained from different sources.

\section{RESULTS AND DISCUSSIONS}

The results show that there are still some weaknesses in every aspect of the evaluation of guidance and counseling program in the state schools. The weaknesses certainly impact on exercising the effectiveness of the guidance and counseling evaluation, so that the program quality that has been implemented cannot be comprehensively revealed. Here will be described the results and discussion of the evaluation of the program conducted by the guidance and counselling teachers at the schools where the data is obtained from data reduction, presentation and conclusion.

The teachers are already able to determine the program components to be evaluated, but they still do not yet comprehensively understand how to evaluate each component of the program. The guidance and counseling program is certainly designed to be implemented and evaluated for its appropriateness to determine the achievement of the objectives that have been planned. If the components that have been implemented are not evaluated, then the teachers will not be able to identify the success rate of the program. The components in question include basic services, responsive services, individual planning, and system support.

Most teachers do not yet understand various evaluation models that can be used in the implementation of program evaluation. Understanding the evaluation models is very important for the teachers, because these evaluation models will be used as the references in carrying out the evaluation in their schools. The guidance and counselling program evaluation models will help them to identify some components to be evaluated. There are some important models such as goal-oriented evaluation, formative, summative, and CIPP. There are some teachers who use formative and summative models, but after being asked more deeply in they apparently cannot describe the use of those evaluation models correctly.

Some are already able to determine the evaluation instruments used in both the test and non test, but not optimally used. The use of instruments is not merger and used only one time, so it does not really represent the students' achievement in participating the guidance and counseling activities. Supposedly, in using the evaluation instruments, the teachers must be able to collaborate the test and non-test instruments, so that the students' achievement after participating in the guidance and counseling activities can be really identified for sure. The instruments used should also refer to the selected evaluation models that really explore each component in the evaluation models used.

The data collection done by the teachers does not mostly follow the procedures in effective and efficient data collection. They do not yet master correctly various procedures to be followed when collecting the data, making the data collection process is carried out without clear procedures. They should first consider whether using oral or written instruments, who will assess, when and where the assessment process has been formatted clearly and systematically. Thus, the data obtained is exactly proper with their expectation.

The guidance and counselling teachers monitor the results of the implemented program only at glance because it is only a cursory monitoring. The monitoring process of the implementation results should be more in-depth in order to know whether the program has been implemented well or not. Monitoring is carried out both inside and outside the classroom and to assess the students' abilities to solve various problems at hand.

The guidance and counselling teachers already present the data, analyze and write the evaluation report well, but because they do not use the right models, the data presentation and analysis created in form of a report do not fully reveal that the results are valid. It will certainly have an impact on the next program. The valid analysis results will provide good inputs to the next program in order to better adapt to the students' needs. Instead, the less valid ones will not provide significant inputs to the next guidance and counseling program. This will result in the guidance and counselling program from year to year, there will be no better change, and the students' problems will also never be resolved significantly.

Some factors inhibiting the implementation of guidance and counselling evaluation include less allocation time, standard system, incomplete data, thus the evaluation process is still minimal. According to the writer, those obstacles are simply classic reasons, but if they have high interest in performing their duties, these problems can be properly solved. According 
to the writer, in fact, there are some things that become the main obstacles in the implementation of the evaluation program in the school, such as lack of knowledge and understanding about the evaluation of guidance and counselling program itself, lack of interest in developing professional competencies, and lack of guidance to the teachers in implementing the program evaluation. Some of these factors lead to insignificant results of the program evaluation, so there will be no better change for the guidance and conselling program, and eventually the program implemented will not be able to help the students to achieve their optimal development.

\section{CONCLUSIONS}

Based on the results, it can be concluded that: (1) the evaluation of the guidance and counselling program in the State Senior High Schools of Singkawang still has many weaknesses, from the stage of determining the program components to be assessed, selecting the evaluation models to be used, selecting the assessment instruments, determining data collection techniques, creating a system for monitoring the implementation of the program, presenting the data, analysis and evaluation report, (2) some factors inhibiting the implementation of the program evaluation are lack of knowledge and understanding by the guidance and counselling teachers, lack of interest in developing professional competencies, and lack of guidance in implementing the evaluation of guidance and counseling program.

\section{REFERENCES}

1. Arikunto, S. dan Cepi. 2004. Evaluasi Program Pendidikan. Jakarta: PT Bumi Aksara

2. Depdiknas. 2007. Rambu-rambu Penyelenggaraan Bimbingan dan Konseling dalam Jalur Pendidikan Formal. Bandung: Jurusan PPB FIP UPI

3. Fitzpatrick, J. L., Sanders, J. R \& Worthen, B. R. 2004. Program Evaluation :Alternative Appoarch and Practical Guideline. Boston: Allyn and Bacon

4. Gibson, RL \& Mitchell MH. 2011. Bimbingan dan Konseling. Yogyakarta: Pustaka Pelajar

5. Gysbers, N. C. \& Henderson, P. 2006. Developing \& Managing Your School Guidance and Counseling Program. Alexandria: American Counseling Association

6. Moleong, L.J. 2014. Metode Penelitian Kualitatif. Bandung : Remaja Rosdakarya

7. Natawidjaya, Rochman. 1978. Pendidikan Nasional. Jakarta: Deppdikbud

8. Sugiyo. 2011. Manajemen BK di Sekolah. Semarang: Widya Karya

9. Sugiyono.2009. Metode Penelitian Pendidikan Pendekatan Kuantitatif, Kualitatif dan R \& D. Bandung: Alfabeta.

10. Staffelbeam, Daniel L. 2003. Institutionalizing Evaluation in Schools. Journal. Volume 9, 2003, pp 775-805

11. Winkel \& Sri Hastuti. 2004. Bimbingan Dan Konseling Di Institusi Pendidikan. Yogyakarta: Media Abadi

12. Yusuf, S. 2009. Program Bimbingan dan Konseling di Sekolah. Bandung: Rizqi Press

\section{Author biography with photo}

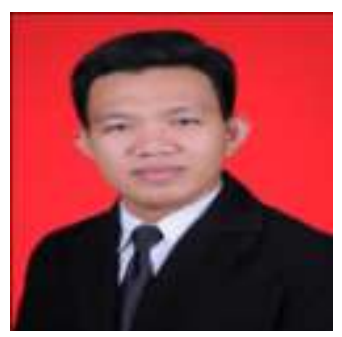

Abd. Basith, born in Ketapang, December 29, 1988. Born of a father and mother named Mr. Mimin Suparno, S. Pd and Mrs. Rolina. Married to Nur Fitriana, S. Pd and happing a son named Adnan Abdullah Hafizh. The last Master of Education Guidance and Counselling of Semarang State University in 2015. Now serving as a lecturer at the STKIP Singkawang, West Kalimantan, Indonesia.

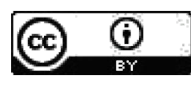

This work is licensed under a Creative Commons Attribution 4.0 International License.

DOI : 10.24297/ijrem.v7i5.4328 